\title{
Emperor and author: The writings of Julian the Apostate, eds. NiCHOLAS BAKER- Brian, Shaun Tougher, The Classical Press of Wales, Cardiff 2012, pp. 384.
}

The volume is a result of an eponymous conference which took place at Cardiff University between $16^{\text {th }}$ and $18^{\text {th }}$ July 2009 . It was organized by the Cardiff School of History and Archaeology (now Cardiff School of History, Archaeology and Religion). The papers included show excellent scholarship and make for an engrossing reading for anyone interested in the emperor Julian and his times in general, and in his literary work in particular. It comes not long after the publication of another conference volume, edited by Christian Schäfer ${ }^{1}$, which focuses on some of the more specific aspects of the last pagan Emperor's activity. While addressing in passing some of the same aspects as those examined in the German volume, the British publication is wider in its scope and focus. Another recent publication touching on similar themes as those examined in the presented volume, and perhaps more innovative in its findings than the Schäfer volume, is the $17^{\text {th }}$ volume of Antiquité Tardive, focusing on the Emperor's life, his legislation and his religious policy. It includes a short but insightful paper by Alberto Quiroga, who convincingly argues that Misopogon should be read as a statement of the Emperor's agenda rather than an attempt to persuade the Antiochenes to Julian's views ${ }^{2}$, and an otherwise interesting paper by J. Torres ${ }^{3}$.

Each of the chapters is accompanied by references, some of which include lengthy and detailed additional notes. The main body of the book is preceded by an introduction written by Shaun Tougher and Nicholas Baker-Brian, and followed by an extensive bibliography and an index. The introduction provides key biographical information about the titular Emperor, focusing in particular on his literary work and its

1 Kaiser Julian 'Apostata' und die philosophische Reaktion gegen das Christentum, ed. C. SCHÄFER, Berlin-New York 2008.

2 A. Quiroga, Julian's Misopogon and the subversion of rhetoric, ATa 17, 2009, p. 127-135.

3 J. ToRres, Emperor Julian and the veneration of relics, ATa 17, 2009, p. 205-214. later scholarly reception and analysis, including the most recent texts devoted to the subject. The authors explain that it was the relatively small amount of attention that Julian's works have received (compared to the Emperor himself and his other accomplishments and activities) that prompted organisation of a conference devoted to his writings in the first place, and it has to be said that the quality of papers read at the conference and subsequently edited for the needs of the book goes a long way to expand the understanding of Julian as an author. The remaining part of the introduction consists of a brief overview of the papers included in the volume.

The book presented here is divided into nineteen chapters, written by authors from across Europe (mainly United Kingdom) and United States, and is devoted to all aspects of Emperor Julian's literary activity. It touches on a wide range of aspects of literary culture of the time, and addresses and confronts modern scholarship of the subject. One of the strong points of The Classical Press of Wales publication is the wide range of sources employed by the book's contributors, who used literary, epigraphic, numismatic and statuary material in their research.

Chapter one, Julian the writer and his audience (p. 1-18) was written by Susanna Elm (University of California, Berkeley). This paper that opened both the conference and the volume provides additional information on Julian and his place in history and literature. It draws attention to the fact that, unlike the imperial person, the research on Julian's writings has not previously been a major area of study, and provides possible reasons for this. The role of Gregory of Nazianzus in shaping the image of Julian is explored in some detail, and Julian's influence on the development of the Church is examined. By painstakingly responding to Julian's writings in an attempt to shame him and his memory in Orations 4 and 5, Gregory laid out in the process much of the theology that shaped Christianity afterwards. 
Chapter two, Reading between the lines: Julian's First panegyric on Constantius II (p. 19-24) was written by Shaun Tougher (Cardiff University). Its focus is primarily on the interpretation of Julian's First panegyric on Constantius. Briefly introducing older scholarly assessment of the panegyric by, e.g., Joseph Bidez and Polymnia Athanassiadi, the author questions some of the existing assumptions - such as the purpose of the panegyric, or its intended audience. $\mathrm{He}$ then proceeds to investigate Julian's models for his panegyric, such as Themistius, Libanius and Dio, before turning to look at the Menandrian model - known very well to Julian, but not slavishly followed. Analysis of the panegyric, both its structure and content, including some unusual for such type of work remarks, has led the author to suggest possible subversive motives in writing the panegyric. Conceding that the interpretation of Julian's panegyrics might vary depending on the understanding of their author, Shaun Tougher concludes that the analysed text has a lot to offer to a careful reader.

Chapter three, 'But I digress...': Rhetoric and propaganda in Julian's second oration to Constantius (p. 35-46) by Hal Drake (University of California, Santa Barbara) is opened by a jocular paragraph addressed to the readers, intended to draw attention to the highly unusual style employed by Julian in his second panegyric. Depending on one's interpretation of that work, it can be treated either as a coherent whole comprised of rhetorical and philosophical parts, or a work that is seemingly praising Constantius while at the same time attacking him. After analysing the panegyric and looking into potential reaction with which it might have been met at the court, Hal Drake proposes that perhaps the text was never intended to be heard by Constantius, and may have been in fact a parody. This thought is explored in more detail, and accompanied with insights into Julian's concept of an ideal ruler that can be found in the text. The paper ends with a brief remark on how Julian's own portrait might have appeared different from the one painted by himself if sources allowed us to see Constantius' perspective of his younger relative.

Chapter four, Is there an Empress in the text? Julian's Speech of thanks to Eusebia (p. 47-59) by
Liz James (University of Sussex) begins with remarks on how little is known about the titular work, and a question: who is this speech actually about? Eusebia, Constantius, perhaps even Julian himself? The speech is often treated as sincere, especially in the light of what Ammianus has to say on the empress. The speech itself is one of thanks, the subject - an imperial woman - rare, but not unique. Menander's model of the speech is followed, with some necessary changes in regard to the virtues described. As with most such speeches, the praise created certain expectations - the addressee was expected to uphold the idealised image. Praise of Eusebia's kindness and clemency could have been, however, read as a jab at Constantius, implying that the emperor himself lacked these qualities. Furthermore, some of the passages may be read as hidden accusations or insults against the empress. The chapter's author remarks that there are many more questions that can be asked about this speech. The chapter ends with an observation on how the portrayal of imperial women tells very little about the women involved, as it focuses almost entirely on their role in the lives of the emperors.

Chapter five, Julian's 'Consolation to Himself on the Departure of the Excellent Salutius'. Rhetoric and philosophy in the fourth century (p. 60-74) by Josef Lössl (Cardiff University) opens with a few remarks taken from Bouffartigue's analysis of the speech. The work itself is a clear example of a consolatio - the intended addressee, along with Julian himself, is Salutius, identified as Secundus Saturninus Salutius, who accompanied Julian in Gaul and became the future emperor's friend. A discussion on the possible influence of Cicero on Julian's work is present. The paper then analyses Julian's notion of friendship and the topoi thereof that he uses. The paper's author also draws attention to the philosophical tone of Julian's letter, the general avoidance of mythological deities and, instead, references to a philosophical, rather than Christian, monotheism. The chapter ends with a few reflections on the ending of Julian's Consolation, and a conclusion that the whole work should be classed as both fully rhetorical and fully philosophical and stresses its importance for understanding 
Julian's early career as well as the intellectual culture of the time.

Chapter six, The tyrant's mask? Images of good and bad rule in Julian's 'Letter to Athenians' (p. 75-90) by Mark Humphries (Swansea University) begins with remarks on the work's unique nature - it systematically presents an emperor's duties in a work written by someone who was a ruler himself, and explains reasons behind accepting by Julian the title of Augustus conferred on him by his troops, in an age when usurpations were common. The paper's main goals are: analysis of the letter, with a focus on its polemical nature, setting of the context in which it was written, and finally examining Julian's explanation for his usurpation. The date of the composition, the intended audience and its form are discussed. It would seem that this is the first public document mentioning Julian's adherence to non-Christian deities - they are called to witness that Julian's cause is just. A detailed analysis of arguments brought forth by Julian in the letter is then made, with some emphasis on the precarious situation and apparent lack of wider support the pagan emperor had at that time. Following the - somewhat disingenuous protestations of innocence, Julian's letter then indirectly but clearly presents Constantius as a tyrant. This is then contrasted with a very different line Julian took after Constantius' death, indicating that the Letter was in large part written for a specific set of circumstances, and ideas contained within are not particularly consistent with Julian's later actions.

Chapter seven, Julian's 'Letter to Themistius' - and Themistius' response? (p. 91-103) by John W. Watt (Cardiff University) points to the importance of the titular letter for understanding Julian as both an author and an emperor. Julian's text is a reply to a now lost letter by Themistius, in which the philosopher expressed his views on kingship. Julian's disagreement is indicated by the detailed ideas the emperor had on ruling. It remains unclear, however, just how sharp the disagreement was; lack of a definite extant reply by Themistius could either indicate that the discussion ended with Julian's rejection of the philosopher's ideas, or the following correspondence may have been simply lost. There are, how- ever, surviving texts in Arabic which may well be translations of Themistius' reply; analysis of those follows. The presented text does not make mention of philosopher-kings or the divine nature of kingship, which were rejected by Julian, and instead focuses on the nature of human society and the virtues of a king. The chapter's author then ponders whether Themistius might have at least partially convinced Julian of his views, and considers the possibility that John Philoponus' De Opificio Mundi may have been indirectly, through Themistius, influenced by Julian's own ideas of kingship.

Chapter eight, The emperor's shadow: Julian in his correspondence (p. 105-120) by Michael Trapp (King's College London) begins with some detailed remarks on the difficulty of establishing the exact number of surviving letters by Julian. This is followed by a brief overview of the letters by Julian, and comments on them from both ancient authors and modern scholars. Julian's adherence to proper models and styles is remarked upon. After a brief look at the public communications by Julian, the following part of the chapter focuses on his personal correspondence. The problematic authorship of the letters written in sophistic style, as the author remarked after a brief overview of those, caused him to examine other examples of the emperor's epistolography. The chapter's author then asks whether the "pastoral" letters by Julian can be classed as separate from both private and standard public correspondence, and whether their style was deliberately chosen by Julian, or whether it was employed without particular deliberation. Stating that he cannot provide any definite answers to these questions, the chapter's author subsequently examines a few of the letters that fall somewhere between the 'sophistic' letters and the public messages, and concludes with a reflection on Julian's complaint about too many petitions and letters requiring his attention from his last letter to Libanius.

Chapternine,Julianthelawgiver (p.121-136) by Jill Harries (University of St. Andrews) explores Julian's legislative activity. It is examined from three perspectives: the emperor's own, expressed in laws or letters containing legal rulings; that of Ammianus; and the one emerging 
from the Theodosian Code. Regarding the first, it is more than likely that at least some of the laws were simply approved by Julian, but not redacted by him personally. In general, though, Julian provides ample reasons and moral explanations for his laws. Regarding the second, the chapter's author remarks briefly on Ammianus' comments, noting the overall positive, though occasionally critical, attitude of the ancient historian towards Julian's legislative efforts. Finally, the Julian of the Theodosian Code is much more concise - as the redactors were cutting down the number of words of the earlier legislators. In this particular case, however, while Julian's laws (often concerned with cost cutting, and sometimes dealing with very minute details) are respected as those of a legal emperor, their intent is occasionally ignored and certain details (or whole passages) omitted, in particular when anti-Christian legislation is concerned. The chapter ends with a remark on the exceptional, perhaps excessive, influence of Julian's personality on his legislation.

Chapter ten, Words and deeds: Julian in the epigraphic record (p. 137-157) by Benet Salway (University College London) begins with an overview of recorded inscriptions regarding Julian, and a mention of studies by Arce and Conti on the subject. The chapter's author aims to isolate the inscriptions that may refer to texts by Julian and to analyse them. Consideration is given to the different periods during which the known inscriptions were made, as well as to the material on which the preserved inscriptions were carved; only the ones on stone survive, even though it is otherwise known at least some were originally in bronze. A look at geographic distribution of the inscriptions follows, and includes an analysis of a number of inscriptions devoted to Julian's deeds. The chapter then focuses on a particular Julianic inscription, omitted in Arce's and Conti's works. The inscription is then compared with a version of the same law included in the Theodosian Code. The chapter concludes with remarks on the relatively low importance assigned to the person of an emperor in his legal inscriptions, compared to the fact they were pronounced with imperial authority.
Chapter eleven, Julian and his coinage: a very Constantinian prince (p. 159-182) by Fernando López Sánchez (Jaume I University, Castellón de la Plana) opens with remarks on the relative abundance of information we possess about emperor Julian as a person, and how that might have caused his political persona to be, at least partially, obscured. Remarks on Bowersock's and Arce's works follow; subsequently, noting the cautious approach of many leading scholars to coin iconography and legends, the author proceeds to analyse the narrative emerging from Julian's coinage. The chapter explores in turn various series of coins featuring Julian, from the earliest issued by Constantius II to Julian's own, devoting much in-depth attention to the pagan emperor's political and religious agenda expressed in numismatic form. The chapter ends with remarks on the clarity of message of Julian's coinage, not hindered by differences resulting from wide geographic distribution of the mints or the communities they were supplying - and a comment on Julian's image emerging from his coins, showing him as a good emperor in terms of administrative and military efforts.

Chapter twelve, Roman authority, imperial authority and Julian's artistic program (p. 183-211) by Eric R. Varner (Emory University, Atlanta), begins with remarks on the abundance of iconographic and written material regarding Julian, and the increasingly individualistic and less conforming to Constantinian standards presentation of the emperor as his reign progressed. A detailed analysis of Julian's portrayal on coins and in sculpture follows, focusing on original close adherence to Constantinian model and the deviations from it. Elements such as hair, facial hair, clothing (especially the paludamentum and pallium) and the crown are examined. Subsequently, similarities between the portrayal of Julian and older models are explored. Similarity between the way Julian was presented and known portrayals of Numa Pompilius, Pythagoras, Marcus Aurelius and Alexander is discussed at some length. Subsequently, attention is given to Julian's program and ideology expressed in coinage. Closing remarks note Julian's attempts at creating an image of the imperial person and 
the state that amalgamated Roman and Greek traditions and conventions.

Chapter thirteen, Julian's 'Hymn to the Mother of the Gods': The revival and justification of traditional religion (p. 213-227) by J.H.W.G. Liebeschuetz (University of Nottingham) begins with remarks on Julian's efforts in presenting an allegoric interpretation of pagan philosophy in a Neoplatonic spirit; his two hymns (to Cybele and to Helios) and the response to the Cynic Heraclius are an expression of this. A brief outline of the Neoplatonic concept of the world and its creation follows, with a comment that both Julianic hymns are closer to sermons than poems. The influence of Iamblichus on Julian's theology is stressed, as well as the importance of the Cynics, who spurred the emperor to formulate counterarguments against their teachings. The festival of Cybele and Attis is examined, and its Julianic reinterpretation presented. The chapter ends with a quote from the Hymn, presenting the various aspects of religion Julian was attempting to create.

Chapter fourteen, Julian's 'Hymn to King Helios': the economical use of complex Neoplatonic concepts (p. 229-237) by Andrew Smith (Trinity College Dublin) beings with asserting the influence of Iamblichus on Julian's theology, and the purpose of the hymn to Helios as determining the god's place in the universe. The universe itself is explained as well, but that is not, the chapter's author states, the main purpose of the poem. A look into the Neoplatonist vision of the universe, and Julian's interpretation of it, follows. Subsequent passages are devoted to detailed analysis of the Neoplatonic hierarchy of hypostases and the place and role of Helios within it. In conclusion, the chapter's author states that Julian's use of Neoplatonic framework allowed the emperor to express his own religious views.

Chapter fifteen, The forging of an $\mathrm{Hel}$ lenic orthodoxy: Julian's speeches against the Cynics (p. 239-250) by Arnaldo Marcone (Roma Tre University) opens with a brief overview of the history of the Cynic movement and its status during late antiquity, with a note on the Cynic rejection of traditional pagan religion making the movement similar to Christianity, in a lim- ited way. Rejection of the traditional religion by the Cynic Heraclius caused Julian to write an impassioned reply to views he considered blasphemous. The emperor rejected contemporary Cynics as frauds and condemned them for choosing only what was easiest about their philosophy, maintaining that the earlier representatives of the movement (in particular its founder Diogenes) followed the true tenets of Cynicism. The concepts of ascetism and parrhesia in the context of Cynic philosophy are explored. The chapter ends with remarks on the - impossible to accept for Julian - Cynic use of parrhesia and the use made of very similar techniques by Christians.

Chapter sixteen, The Christian context of Julian's 'Against the Galileans' (p. 251-261) by David Hunt (Durham University) opens with a commentary on how little is known about the titular work - the original title and length are uncertain, the only surviving fragments come from a Christian polemic work by Cyril of Alexandria. The three main lines of argument presented by Julian are discussed (the origin of the concept of God, comparison between Greek and Jewish understanding of God, and finally Christian rejection of both these traditions). The influence of Celsus and Porphyry on Julian is discussed, and an argument that Porphyry's reasoning might have had a greater impact on Julian's work is made, supported by evidence from Libanius. The main part of the chapter focuses on Julian's denial of the divinity of Jesus, a theme the chapter's author feels has not been stressed sufficiently before. Influence of Aetius and Photinus on Julian's line of argument is examined, and an overview of points made by the emperor follows. The chapter's conclusion once again stresses the importance of the Christian debate on the divinity of Jesus to Julian's work.

Chapter seventeen, The politics of virtue in Julian's 'Misopogon' (p. 263-280) by Nicholas Baker-Brian (Cardiff University) begins with a look at Julian's stay in Antioch prior to his Persian expedition, based chiefly on the works of Ammianus and Libanius. The Antiochene dislike of Julian and its causes are explored. The chapter's author then proceeds to analyse 
Misopogon itself, and noting the role of irony in that work, comments on the inversion of praise and accusation and bringing forth temperance as Julian's greatest virtue. It is also noted that Constantius II was known for adhering to the model of self-control and temperance during his reign, and this image was only challenged by Julian and Ammianus at a later date. Misopogon, indirectly, also struck at Constantius' reputation among the Antiochenes, who held the late emperor in high regard. Ultimately, Julian's subversion of the genre served to criticise the Antiochenes and the memory of Constantius as well as the assumption behind the encomia themselves that those listening to such orations will follow the example of praised rulers.

Chapter eighteen, The 'Caesars' of Julian the Apostate in translation and reception, 1580 - ca. 1800 (p. 281-321) by Rowland Smith (University of Newcastle) begins with a brief overview of the discussed work itself, followed by a look at the history of translation of the work during the discussed period. Translations by Grangier and Cunaeus are mentioned, more attention is however given to Spanheim and the wide circulation of his version of Julian's work; a version which would subsequently be criticised by Le Bletterie as excessively annotated with comments that often served to make the whole less approachable. Other versions are mentioned, including the first into English, from 1784, by John Duncombe. The figure of John Duncombe and his associates is presented, and notes on the heavy reliance of Duncombe on the earlier work of La Bletterie is noted. Subsequently, much attention is devoted to the religious affiliations of the Julianic scholars of the age, and the way in which it affected their reception of Caesars. The following section of the chapter focuses on iconographic representations of Julian. Some of the political implications of the work during the Enlightenment are noted as well. The understanding and reception of Julian by $18^{\text {th }}$ century authors and translators follows. The chapter ends with a detailed look at Fielding's A journey from this world to the next, first published in 1743, and its humorous re-interpretation of Julian.
Chapter nineteen, Afterword: Studying Julian the author (p. 323-338) by Jaqueline Long (Loyola University Chicago) begins with analysis of the physical description of the emperor by the ancient authors, and its implications. This allows us to place Julian in the context of contemporary culture - an approach, the chapter's author argues, that has been previously neglected. Subsequently, scholarly approaches to Julian are briefly examined: the interpretations of Bouffartigue, Gleason, Relihan, Athanassiadi and Bowersock are mentioned. Impact of MacCormack's work on imperial ceremony and its implications for the understanding of panegyrics is noted, and this commentary serves to open an elegant and observant summary of the preceding chapters. The text ends the main body of the book with a portrayal of Julian that combines the insights encompassed in the preceding chapters.

The volume offers a considerable number of well researched and exhaustively annotated papers devoted to the literary activity of the Emperor Julian. Due to careful planning, the papers address in some manner all of the Emperor's works; it should also be noted that there is very little overlap in the papers' contents. On the other hand, this could be viewed as the volume's weakness; it may be seen as lacking a clear internal coherence. This should not, however, elicit strong criticism as it is nearly impossible to avoid in a conference volume. Important events from the life of the last pagan Emperor, while often mentioned to provide context for his literary activity are, not the focus of the volume, and the book assumes a degree of pre-existing knowledge about both Julian and the Roman history in the fourth century. The comprehensive index and collected bibliography, features that occasionally are still missing from otherwise excellent volumes published in recent years, are highly useful in navigating the volume and following the references. The book should prove to be a highly valuable asset for scholars interested in the person and the writings of the last pagan Emperor and the literary culture of his times.

Michat Zytka (Cardiff) 